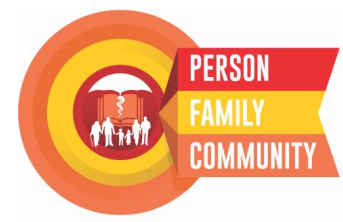

Journal Homepage: https://jurnal.ugm.ac.id/rpcpe

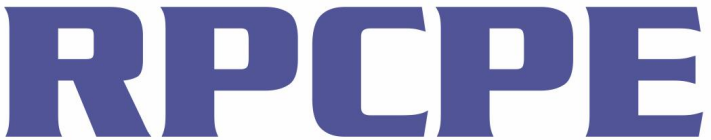

ISSN 2613-943X (print)

ISSN 2620-5572 (online)

Review of Primary Care Practice and Education (Kajian Praktik dan Pendidikan Layanan Primer)

\title{
The Effect of Reproductive Health Counseling to the Perception on Prevention Behavior of Leucorrhea in Female Students at SMAN 1 Temon (Based on the Health Belief Model/HBM Theory)
}

\author{
Beti Wulansari ${ }^{1}$, Wahyudi Istiono ${ }^{2}$, Shinta Prawitasari ${ }^{3}$ \\ ${ }^{1}$ Puskesmas Temon 2; Kulon Progo; Yogyakarta; Indonesia \\ ${ }^{2}$ Department of Family and Community Medicine; Faculty of Medicine, Public Health and Nursing; Universitas Gadjah Mada; \\ Indonesia \\ ${ }^{3}$ Department of Obstetrics and Gynecology; Faculty of Medicine, Public Health and Nursing; Universitas Gadjah Mada; Indonesia \\ Corresponding Author: \\ Beti Wulansari: Puskesmas Temon 2, Jalan Raya Wates Purworejo km 16, Tanggalan Palihan, Temon, Kulon Progo, Yogyakarta - \\ 55654, Indonesia \\ Email: beti.wulansari@gmail.com.
}

To cite this article:

Wulansari B, Istiono W, Prawitasari S. The Effect of reproductive health counseling to the perception on prevention behavior of leucorrhea in female students at SMAN 1 Temon (Based on the Health Belief Model/HBM Theory). Rev Prim Care Prac and Educ. 2018; 1(3): 1160-122.

\begin{abstract}
Background: Leucorrhea is a problem that is often experienced by women. Female adolescents have inadequate knowledge about handling and preventing leucorrhea. This inadequate knowledge has an impact on the perception that leucorrhea will not affect their health. But in reality, for the last 3 (three) years from 2014 to 2016, there was an increase in complaints according to the screening results by Puskesmas Temon 2 (Community Health Center). Because of this reason, interventions are needed regarding the knowledge about leucorrhea prevention applying the Health Belief Model (HBM) theory, including perceptions of seriousness, vulnerability, benefits, obstacles, and impulse to act that can be measured by a perceptual score. Objectives: This study aimed to determine the effect of reproductive health counseling on the perceptual score of seriousness, vulnerability, benefits, obstacles, and impulse to act involving female students' perceptions in leucorrhea prevention behavior of SMAN 1 Temon (Senior High School) before and after health counseling. The score was measured by the HBM. Methods: The research was a quasi-experimental study with a time series design. The population of this research was the female students of class X and XI SMAN 1 Temon. The sample consisted of 55 female students who had fulfilled the inclusion and exclusion criteria by using simple random sampling technique. Data were analyzed using eepeated ANOVA test with significance level $(\alpha)$ of 0.05 . Results: The results of this study indicated that there were significant differences in perception scores $(p=0.000)$ before counseling and after counseling in perceptions of seriousness in prevention, vulnerability to leucorrhea, benefits in prevention, barriers to preventive action, encouragement to act and total HBM score. Conclusions: Reproductive health counseling about leucorrhea based on the Health Belief Model theory is effective to improve female adolescent students' perception in taking action to prevent leucorrhea, especially in perception scores of seriousness, vulnerability, benefits, obstacles, and impulse to act in leucorrhea prevention behavior of female students in SMAN 1 Temon.
\end{abstract}

Keywords: Health Belief Model / HBM, Leucorrhea, Prevention behavior, Female adolescents

\section{BACKGROUND}

Leucorrhea often occurs in female adolescents, especially in Asia where $76 \%$ of woman experience leucorrhea and in Indonesia alone there are $75 \%$ of women who experience leucorrhea once and $45 \%$ experience leucorrhea twice or more due to the humid climate that make conditions susceptible to leucorrhea caused by Candida albicans and parasitic fungal infections ${ }^{1,2}$. An abnormal leucorrhea can cause feelings of discomfort, and over extended periods of time can cause serious illness, including pelvic infections and infertility ${ }^{3}$. Some coping efforts involve using antiseptic soaps to wash the genital organs. The use of antiseptics actually disturbs the vaginal ecosystem, especially the $\mathrm{pH}$ of bacterial life, characterized by leucorrhea ${ }^{4}$. Based on the statistical data in 2009, in Daerah Istimewa Yogyakarta (DIY), about $68 \%$ of 2.9 million people aged $15-24$ years 
experienced discomfort from leucorrhea ${ }^{5}$.

Data from the Puskesmas Temon 2 indicated there were complaints of leucorrhea and itching around the genital area of the female students in SMAN 1 Temon and SMK (vocational high school) Ma'arif during the last three years. The results of a preliminary study revealed that their personal hygiene was not good, the habit of wearing tight pants, rarely replacing the sanitary napkins and wrong direction when cleaning after defecation caused an increase in complaints of genital organ disorders ${ }^{5,6}$.

The Health Belief Model (HBM) is a traditional sociopsychology model. The emergence of this model is based on the fact that health problems are characterized by the failure of people or communities to support prevention and healing efforts from disease. Rosenstock mentioned that HBM has four perceptions, namely perception of seriousness (perceived seriousness) which is a feeling of seriousness of disease, perception of vulnerability (perceived vulnerability) which is perceived susceptibility to risk that will arise against him/her, perceived benefits (perceived benefits) are an individual evaluation of the effectiveness carried out to overcome the health problems they experienced, and perceived obstacles (perceived obstacles) that are perceived by individuals to act as obstacles in carrying out the right behavior ${ }^{7}$. Oliver and Berger added the cues to action factor to explain $\mathrm{HBM}^{8}$.

The purpose of this study was to determine the effect of reproductive health counseling on perceptual scores of seriousness, vulnerability, benefits, obstacles, and impulse to act in leucorrhea prevention behavior of female students in SMAN 1 Temon before and after counseling measured by the traditional HBM Theory. The research stages were as follows: measurement of perception scores using questionnaires before the counseling, giving female adolescent reproductive health counseling related to leucorrhoea, measuring perception score immediately after counseling, and measuring perception score one month $(\mathrm{H}+30)$ after counseling in order to better evaluate the implementation of counseling.

\section{RESEARCH METHODS}

This research was a study using quantitative data analysis. The research design was quasi-experimental with a pre and post-test without control with time series design. The population of the study was female students of SMAN 1 Temon especially class $\mathrm{X}$ and XI, which amounted to 128 students. The sample size of this study was calculated based on the formula ${ }^{9}$ :

$$
\mathrm{n}=\frac{Z_{1-\frac{\alpha}{2}}^{2} P(1-P) N}{d^{2}(N-1)+Z_{1-\frac{\alpha}{2}}^{2} P(1-P)}
$$

Notes:

$Z_{1-\frac{\alpha}{2}}^{2}=$ Statistic $Z(Z=1.96$ for $\alpha=0.05)$

$\mathrm{N}=$ Population (128 students)

$\mathrm{P}=$ Proportion $(50 \%)$

$\mathrm{d}=$ Precision $(10 \%)$

Based on calculations, as many as 55 research subjects were selected by simple random sampling method.

The inclusion and exclusion criteria were as follows:

Inclusion Criteria:

a. Female students of SMAN 1 Temon with active student status of the school, class X and XI.

b. Age $14-18$ years.

c. Willing to be a respondent.

Exclusion Criteria:

a. Not present at the time of data retrieval.

b. Have been following reproductive health counseling.

An HBM theory application questionnaire on the effort of leucorrhea prevention was used as a research instrument. The questionnaire consists of 30 questions divided into 5 sub-chapters. Validity tests used product moment correlation and reliability test used Alpha Cronbach test ${ }^{10}$. Validity and reliability test results obtained 25 valid and reliable statements.

Statistical analysis was performed by bivariate analysis using repeated ANOVA tests if the data were normally distributed, while multivariate test used Pairwise comparisons tests ${ }^{11}$.

\section{RESULTS}

Most of the respondents were 16 years old and had been exposed to information and experienced discomfort leucorrhea. As for their habits, they changed their underwear two times daily, changed sanitary napkins $\geq$ $3 \mathrm{x}$, used specific feminity soap $\geq 3 \mathrm{x}$, or they sometimes/ never changed feminity soap, sometimes/never replaced sanitary napkins with a cloth that was washed again, and sometimes/never wore panty liner when not menstruating. With other details, Table 1 shows respondents' behavior concerning leucorrhea prevention.

Perception scores in the prevention behavior of SMAN 1 Temon female students before and after getting counseling about the prevention of leucorrhoea indicated there was an increase of the average total score of HBM before the counseling 9.90 to 14.27 after the counseling and a month after pre-test and post-test I to 15.42. Each component also increased in post-test I and post-test II. In detail, the results of the score can be seen in Table 2. 
Table 1. Characteristics of Respondents

\begin{tabular}{|c|c|c|}
\hline Characteristics & $\mathbf{n}$ & $\%$ \\
\hline \multicolumn{3}{|l|}{ Age } \\
\hline 14 years & 4 & 7.27 \\
\hline 15 years & 23 & 41.82 \\
\hline 16 years & 28 & 50.91 \\
\hline Total & 55 & 100 \\
\hline \multicolumn{3}{|l|}{ Leucorrhea Type } \\
\hline Abnormal (Discomfort) Leucorrhea & 49 & 89.09 \\
\hline Non-Abnormal Leucorrhea & 6 & 10.91 \\
\hline Total & 55 & 100 \\
\hline \multicolumn{3}{|l|}{ Information Exposure } \\
\hline Ever & 33 & 60 \\
\hline Never & 22 & 40 \\
\hline \multicolumn{3}{|l|}{ Changing Underwear (in a day) } \\
\hline $1 \mathrm{X}$ & 0 & 0 \\
\hline $2 \mathrm{X}$ & 39 & 70.91 \\
\hline$\geq 3 X$ & 16 & 29.09 \\
\hline \multicolumn{3}{|l|}{ Changing Sanitary Napkins (in a day) } \\
\hline ix & 0 & 0 \\
\hline $2 \mathrm{X}$ & 3 & 4.45 \\
\hline$\geq 3 X$ & 52 & 95.55 \\
\hline \multicolumn{3}{|l|}{ Using Special Feminity Soap (in a day) } \\
\hline $1 \mathrm{X}$ & 12 & 21.82 \\
\hline $2 \mathrm{X}$ & 5 & 9.09 \\
\hline$\geq 3 X$ & 38 & 69.09 \\
\hline \multicolumn{3}{|l|}{ Replacing Special Feminity Soap } \\
\hline Never & 33 & 60 \\
\hline $1 \mathrm{X}$ & 15 & 27.27 \\
\hline $2 X$ & 7 & 12.73 \\
\hline$\geq 3 \mathrm{X}$ & 0 & 0 \\
\hline \multicolumn{3}{|c|}{ Replacing Sanitary Napkins with Washed Cloth } \\
\hline Never & 49 & 89.09 \\
\hline Ever & 6 & 10.91 \\
\hline Often & 0 & 0 \\
\hline \multicolumn{3}{|l|}{ Using Panty liner When Not Menstruating } \\
\hline Never & 34 & 61.82 \\
\hline Often & 1 & 1.82 \\
\hline Sometimes & 20 & 36.36 \\
\hline$\geq 3 \mathrm{X}$ & 0 & 0 \\
\hline
\end{tabular}

Table 2. Perception Score in Leucorrhea Prevention Behavioral of SMAN 1 Temon Female Students Before and After Health Counseling Measured by HBM Theory

\begin{tabular}{lccccc}
\hline \multirow{2}{*}{ Type of Perception } & $\begin{array}{c}\text { Number of } \\
\text { Female Students }\end{array}$ & Pre & Post I & Post II & \multirow{2}{*}{$\boldsymbol{p}$} \\
\cline { 3 - 5 } & 55 & 8.18 & 13.53 & 15.49 & 0.000 \\
\hline Perceptions of Seriousness & 55 & 6.29 & 14.60 & 16.16 & 0.000 \\
Perceptions of Vulnerability & 55 & 11.54 & 15.42 & 16.00 & 0.000 \\
\hline Perceptions of Benefits & 55 & 12.69 & 15.47 & 16.07 & 0.000 \\
Perception of Obstacles & 55 & 10.78 & 12.34 & 13.36 & 0.000 \\
Impulse to Action & 55 & 9.90 & 14.27 & 15.42 & 0.000 \\
\hline HBM & & & & &
\end{tabular}

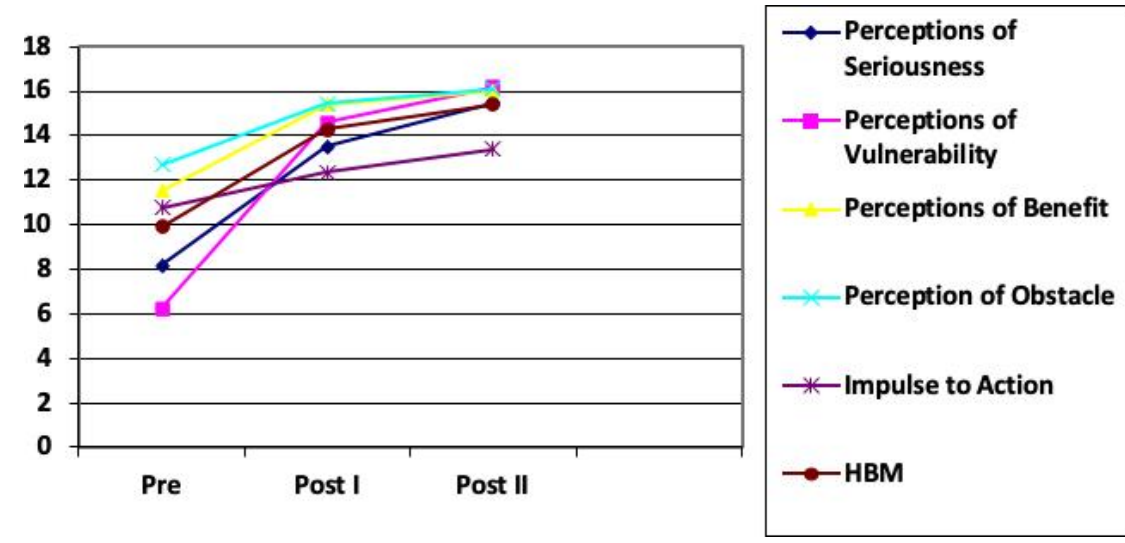

Figure 1. Score Comparison of Perception of Seriousness, Vulnerability, Benefit, Obstacle, Impulse to Action and HBM, Pre-test, Post-test I and Post-test II 
The results of the bivariate analysis showed that there were significant differences in all perception scores between pre-test, post-test I and post-test II.

The pattern of increasing perceptual scores continued to increase after counseling and the following month.
Increased perception scores of seriousness, vulnerability, benefits, obstacles, and impulse to act can be seen in the chart below.

The differences in each treatment on each perception can be seen in Table 3 as follows:

Table 3. Pairwise Comparisons Multivariate Test Results

\begin{tabular}{ccc}
\hline Perceptions & Treatments & $\boldsymbol{p}$ Value \\
\hline Seriousness & Pre Test vs Post Test I & 0.000 \\
\hline Vulnerability & Post Test I vs Post Test II & 0.000 \\
& Pre Test vs Post Test II & 0.000 \\
\hline Benefit & Pre-test vs Post Test I & 0.000 \\
& Post Test I vs Post Test II & 0.000 \\
& Pre Test vs Post Test II & 0.000 \\
\hline Obstacle & Pre Test vs Post Test I & 0.000 \\
& Post Test I vs Post Test II & 0.000 \\
& Pre Test vs Post Test II & 0.000 \\
\hline Impulse to Action & Pre-test vs Post Test I & 0.000 \\
\hline & Post Test I vs Post Test II & 0.000 \\
& Pre Test vs Post Test II & 0.000 \\
\hline HBM & Pre-test vs Post Test I & 0.000 \\
\hline & Post Test I vs Post Test II & 0.000 \\
& Pre Test vs Post Test II & 0.000 \\
\hline & Pre-test vs Post Test I & 0.000 \\
\hline
\end{tabular}

The results of the study showed that there was an average increase of perception scores of seriousness before and shortly after counseling from 8.18 to 13.53 . After a month of the study the result was 15.49 . The results of repeated ANOVA tests on increasing perception of seriousness were found to have a significant difference $(p=0.000)$. Pairwise comparison tests provided the following results on pre-test - post-test I ( $p=0.000)$, pre-test - post-test II $(p=0.000)$, and post-test $\mathrm{I}$ - post-test II after $\mathrm{H}+30(p=0.000)$.

\section{Perceptions of Vulnerability}

The results showed that the average score of vulnerability perceptions of female students of SMAN 1 Temon experienced a significant increase after health counseling about leucorrhea $(p=0.000)$. The increase in scores occurred in all treatments, both in the pre-test - post-test I $(p=0.000)$, pre-test - post-test II $(p=0.000)$, and post-test $\mathrm{I}-$ post-test II after $\mathrm{H}+30(p=0.000)$.

\section{Perceptions of Benefits}

The increases in benefit perception scores were also statistically significant $(p=0.000)$. The increases in the benefit perception occurred in pre-test - post-test I $(p=0.000)$, pre-test - post-test II $(p=0.000)$, and post-test $\mathrm{I}$ - post-test II after $\mathrm{H}+30(p=0.000)$.

\section{Perception of Obstacles}

The results showed that the average score of obstacles perception experienced a good increase shortly after counseling and a month after counseling. The results of the bivariate tests also showed that there was significant difference of mean score of perception before and after the counseling $(p=0.000)$. Differences occurred both in the pre-test - post-test I $(p=0.000)$, pre-test - post-test II $(p=0.000)$, and post-test I - post-test II after $\mathrm{H}+30$ $(p=0.000)$.

\section{Impulse to Action}

The results showed that the average score of the impulse to action experienced a good increase shortly after counseling and a month after counseling. The results of the bivariate test also showed that there was significant difference of mean score of perception before and after the counseling $(p=0.000)$. Differences occurred both in the pre-test post-test I $(p=0.000)$, pre-test - post-test II $(p=0.000)$, and post-test I - post-test II after $\mathrm{H}+30(p=0.000)$.

\section{Health Belief Model / HBM}

Overall the average HBM score was increased and considered statistically significant $(p=0.000)$, in each treatment, both in the pre-test - post-test I $(p=0.000)$, pretest - post-test II $(p=0.000)$, and post-test I - post-test II after $\mathrm{H}+30(p=0.000)$.

\section{Perceptions from Respondents}

Respondents stated counseling about leucorrhea that had 
been conducted was good. The material presented was in accordance with what they expected so far, and the counselor could explain in an easy-to-understand language about the importance of personal hygiene.

\section{DISCUSSION}

\section{Perceptions of Seriousness}

The increase of perception score of seriousness was due to the female students of SMAN 1 Temon feeling that leucorrhea is a serious problem for reproductive health with the result that they will take action to prevent or treat it. This is in accordance with the definition of the perception of seriousness, specifically the perception concerning the sense of seriousness of the disease, if not handled, there will be medical consequences (death, disability, and pain), psychological consequences (depression, anxiety, and fear), and social consequences (impact toward work, family life, and social relations $)^{12}$. Due to the good leucorrhea prevention habits such as frequent information about leucorrhea from TV, community health centers, Internet, and magazines were available to the female students of SMAN 1 Temon, if these continue then the health benefits of action are more than the obstacles that may be found ${ }^{13}$. This finding is in contrast to research which states that most (64.04\%) of female adolescents do not regard leucorrhea as a serious problem ${ }^{14}$.

\section{Perceptions of Vulnerability}

Respondents who did not perceive themselves vulnerable argued that the use of underwear that does not absorb sweat and the use of antiseptic solutions will not lead to leucorrhea, when in fact it facilitates the growth of germs, bacteria, fungi attached to feminine areas while the use of antiseptic changes normal vaginal $\mathrm{pH}$ (4-4.5) to become base/alkaline nature ${ }^{15}$. A person should perceive their vulnerability in taking action to prevent or treat an illness ${ }^{13}$, and this is in accordance with the perception of vulnerability which states that the higher the perception of vulnerability, the greater the perceived threat, and the greater the likelihood that the individual will take action to overcome the problem ${ }^{16}$.

\section{Perceptions of Benefits}

There was an increase in the average scores of perception of benefits because the respondents agree with the benefits of the act of maintaining personal hygiene, the use of special feminity soap with suitable $\mathrm{pH}$, changing pads/sanitary napkins periodically while menstruating, and replacing the underwear at least $2 \mathrm{x}$ a day to reduce the occurrence of leucorrhea in women ${ }^{17}$. Another study suggests that there is a relationship between maintaining the cleanliness of female organs with the incidence of leucorrhea in adolescents in accordance with the perception of the benefits that shows positive health results when a person believes as a result of preventive and treatment actions and consequently will form an action by themself ${ }^{18}$.

\section{Perception of Obstacles}

Respondents considered that there was nothing to prevent them from taking leucorrhea precautions, either from themselves or from outside, and this is in accordance with the definition of obstacles of perception which states that the negative health results when a person believes there are obstacles as a result of the preventive actions coming from within and from outside of the individual.

This result is different from one study which found that the perception of obstacles is very strong in taking precautionary measures, and this is because the respondents may select a bad action in preventing against abnormal leucorrhea, despite knowing the threat to her feminine area $^{14}$. The obstacles felt by the respondents included that they should come to the Puskesmas first. Actually, in order to prevent abnormal leucorrhea, there is no need to come to Puskesmas, but it is sufficient to maintain the hygiene of the feminine area properly. The obstacle factors were not a big problem in taking leucorrhea precautions. This is seen from the results of the study that most respondents had changed the sanitary napkins with a cloth (washed cloth), changed underwear $2 \mathrm{x}$ in a day, and replaced sanitary napkins $\geq 3 \mathrm{x}$ in a day.

\section{Impulse to Action}

The results of the study found that there was a relationship between the impulse to act to take the precaution against leucorrhea. These results are consistent with studies suggesting a relationship of an impulse to act with the prevention of leucorrhea in female adolescents ${ }^{14}$. This is because respondents understand the importance of maintaining the cleanliness of their female organs so as not to cause leucorrhea. Respondents who are not encouraged in taking precautionary measures tend to take unhealthy precautions in preventing leucorrhea.

Factors that play a role in influencing the impulse to act in adolescence are the role of their parents. The role of parents is necessary for changing behavior in adolescents because parents took care of them since childhood so parents should help their children early in changing behavior and train them to familiarize themselves in maintaining the hygiene of the feminine area to prevent the occurrence of leucorrhea ${ }^{15,19}$. Parents, health workers, teachers, peers, electronic media, and print media are the central sources where the respondents get information about leucorrhea, and if the information provided in the prevention of leucorrhea is good then the respondents' actions in the prevention of leucorrhea will be good as well, whereas if the information provided is not good in preventing leucorrhea, then the respondent will take the wrong action.

\section{Health Belief Model / HBM}

Many factors influence the increase in HBM average score, one of which is the effective implementation of reproductive health education about leucorrhea that goes well. This is consistent with the theory which states that health counseling can shape an individual's perception of good health action ${ }^{20,21}$. Another study also states that health counseling can affect the perception of female adolescents in doing leucorrhea prevention 22,23 .

\section{Responses from Respondents}

Leucorrhea problems are not only related to a person's 
medical beliefs and perceptions, but are influenced by culture and social values ${ }^{24}$. This is in accordance with research which states that there is a direct relationship between the incidence of leucorrhea and women's perceptions of leucorhea ${ }^{25}$. But most women consider leucorrhea to be a very natural thing and will not cause harmful effects. Actually, disruptive leucorrhea can be fatal for their health if not handled properly ${ }^{26}$.

The positive results of the study indicate that the provision of health information through counseling can change the female students' perceptions that abnormal leucorrhea if left unchecked can lead to many health problems and possibly death.

Sources of information accessed by adolescents who attend school contribute to improving knowledge, attitudes, and behaviors about reproductive health. Good information will have a positive impact, or vice versa, wrong information can lead to misperceptions. Although information about leucorrhea is abundant and easy accessed, not all information sources are accurate. Reproductive health education about leucorrhea, should be done by parents at home and teachers at school. But the general conditions in our society indicate that reproductive health education was still taboo to be discussed between parents and their children ${ }^{27}$.

The self-perception theory says that the positive or negative perceptions of something depends on the persons' maturity. The factors that influence perception are personal experiences, external factors, culture, media, educational institutions, and emotional state. Good perceptions can be produced as a positive effect of their culture. The influence of important people in the life of female students can also positively affect the attitude of self-control regarding the prevention of abnormal leucorhea ${ }^{19}$.

The adolescent stage is a transition period between immaturity, childhood and adult maturity. In this period of development, it is important to find their identity. Female students will follow the attitude of their role models or the people who are important to them (for example, their mother). Ultimately, this study is expected to encourage the respondents to take better care of themselves and follow proper actions to prevent abnormal leucorrhea.

Counseling conducted in SMAN 1 Temon is considered to be successful because it can improve the perception scores of the female students about the prevention of leucorrhea. Following this research, it is expected that the adolescent reproductive health counseling program will be done periodically in collaboration with the Puskesmas Temon II as a source of health counseling, while the schools are encouraged to conduct reproductive health counseling through the school health unit, with the installation of pamphlets as additional sources of information related to adolescent reproductive health in school magazines.

\section{CONCLUSIONS}

Reproductive health counseling has an effect on increasing perception scores of seriousness, vulnerability, benefits, obstacles, and impulse to act in leucorrhea prevention behavior of female students in SMAN 1 Temon.

\section{Acknowledgment}

Our greatest thanks to the employees of Puskesmas Temon II, IKK staff, teachers and students of SMAN 1 Temon and Ma'arif Vocational School who helped in this research.

\section{Ethical Approval}

This study was approved by The Medical and Health Research Ethics Committee (MHREC) from the the Faculty of Medicine, Public Health and Nursing, Universitas Gadjah Mada, Yogyakarta with the reference number: KE/ FK/0680/EC/2017 dated June 14 ${ }^{\text {th }}, 2017$.

\section{Funding}

Self-funding.

\section{Availability of Data and Materials}

Please contact the author for the availability of data and material through the author's correspondence.

\section{Conflict of Interest}

None.

\section{REFERENCES}

1. Indonesia National Family Planning Coordinating Board (BKKBN). Reproductive health problems in adolescents. Jakarta: BKKBN. 2009.

2. Kent HL. Epidemiology of vaginitis. American Journal of Obstetrics \& Gynecology. 1991 Oct 1;165(4):1168-76.

3. Sweet RL. Pelvic inflammatory disease: current concepts of diagnosis and management. Current infectious disease reports. $2012 \mathrm{Apr}$ 1;14(2):194-203.

4. Mills BB. Vaginitis: beyond the basics. Obstetrics and Gynecology Clinics. 2017 Jun 1;44(2):159-77.

5. Yogyakarta Public Health Office. Kulonprogo Regency Health Profile in 2013. Yogyakarta: Yogyakarta Public Health Office. 2016.

6. Cemek F, Odabaş D, Şenel Ü, Kocaman AT. Personal hygiene and vulvovaginitis in prepubertal children. Journal of Pediatric and Adolescent Gynecology. 2016 Jun 1;29(3):223-7.

7. Rosenstock IM. The health belief model and preventive health behavior. Health Education Monographs. 1974 Dec;2(4):354-86.

8. Oliver RL, Berger PK. A path analysis of preventive health care decision models. Journal of Consumer Research. 1979 Sep 1;6(2):113-22

9. Lemeshow S, Hosmer DW, Klar J, Lwanga SK. Sample size in health research. Yogyakarta: Universitas Gadjah Mada. 1997.

10. Sugiyono. Statistics for research. Bandung: CV. Alfabeta. 2010 (cetakan ke-19).

11. Dahlan MS. Statistics for medicine and health, $3^{\text {rd }}$ Issue. Jakarta: Salemba Publisher. 2010.

12. Maulana HDJ. Health promotion. Jakarta: EGC. 2007.

13. Glanz K, Rimer BK, Viswanath K, editors. Health behavior and health education: theory, research, and practice. New Jersey: John Wiley \& Sons. 2008 Aug 28.

14. Kurniawati C, Sulistyowati M. Application of the health belief model theory in the prevention of pathological leucorrhoea. Jurnal Promkes (Journal of Health Promotion). 2014 Dec;2(2):117-27.

15. Yuliarti N. A-Z woman health \& beauty. Yogyakarta: CV Andi Offset. 2009.

16. Sarafino EP, Smith TW. Health psychology: Biopsychosocial interactions. New Jersey: John Wiley \& Sons. 2014 Jan 13.

17. Anurogo D, Wulandari A. The right way to deal with menstrual pain. Yogyakarta: Andi Publisher. 2011.

18. Setiani TI, Prabowo T, Paramita DP. Cleanliness of female organs and pathological leucorrhoea at santriwati at Al Munawwir Islamic Boarding School in Yogyakarta. Jurnal Ners dan Kebidanan Indonesia (Indonesian Ners and Midwifery Journal). 2015 Mar 1;3(1):39-42.

19. Rembang M, Maramis FRR, Kapantow G. The relationship between 
knowledge and attitude with leucorrhoea prevention measures for female students of SMA N 9 Manado. E-Journal of Sam Ratulangi University. 2012;1-5.

20. Notoatmodjo S. Health Behavior Science. Jakarta: Rineka Cipta. 2010.

21. Daryani S, Shojaeezadeh D, Batebi A, Charati JY, Naghibi A. The effect of education based on a health belief model in women's practice with regard to the Pap smear test. Journal of Cancer Policy. 2016 Jun 1;8:51-6.

22. Fatima $H$, Khan N. Perceptions of women reporting vaginal discharge at gynecology clinics in lahore. J Behav Sci. 2013;23(3):21-34.

23. Noegroho A, Hariadi SS, Priatamtama PW. Factors influencing adolescents' reproductive health behavior of Banyumas district. Jurnal Kawistara: Jurnal Ilmiah Sosial dan Humaniora (Kawistara Journal: Scientific Social and Humanities Journal). 2015;5(1):57-66.

24. Snowden R, Christian B. Patterns and perceptions of menstruation: A World Health Organization international study. New York: St. Martin's Press. 1983.

25. Bro F. Vaginal discharge in general practice-women's perceptions, beliefs and behaviour. Scandinavian journal of primary health care. 1993 Jan 1;11(4):281-7.

26. Kaur J, Kapoor A. Perceptions and knowledge about leukorrhea in a slum dwelling South Asian community. Journal of Family \& Reproductive Health. 2014 Mar;8(1):45.

27. Surjadi C, Pratomo H, Handajani YS. Reproductive reproductive health in adolescents. Jakarta: Proseding Kongres Nasional IX Epidemiologi (Proceedings of the IX National Congress on Epidemiology). 2000. 